\title{
Pemanfaatan Moringa oleifera sebagai Produk Olahan Sehat dan Bernilai Ekonomis bagi Masyarakat di Kecamatan Ratu Samban Kota Bengkulu di Tengah Pandemi Covid-19
}

\section{The Utilization of Moringa oleifera as Healthy and Economical Value Products for the People in Ratu Samban District, Bengkulu City in the Covid-19 Pandemic Era}

\author{
Meilani Belladona $^{1 *}$, Janusi Waliamin ${ }^{2}$ \\ ${ }^{1}$ Program Studi Teknik Sipil Universitas Prof. Dr. Hazairin SH, Jl. Jend. A. Yani No. 1 Bengkulu, Indonesia \\ ${ }^{2}$ Program Studi Manajemen Universitas Prof. Dr. Hazairin SH, Jl. Jend. Sudirman No. 185 Bengkulu, Indonesia
}

\begin{tabular}{|c|c|}
\hline Info Artikel & ABSTRAK \\
\hline $\begin{array}{l}\text { Diterima } 11 \text { Oktober } 2020 \\
\text { Ditelaah } 30 \text { Nopember } 2020 \\
\text { Disetujui 01 Juni } 2021 \\
\text { Tersedia daring } 30 \text { Juni } 2021 \\
\text { *Penulis untuk korespondensi } \\
\text { brilian.tyas@ymail.com }\end{array}$ & $\begin{array}{l}\text { Masa pandemi Covid-19 sangat berpengaruh terhadap perekonomian warga di } \\
\text { Kecamatan Ratu Samban, Kota Bengkulu, Provinsi Bengkulu. Permasalahan yang } \\
\text { ditemui adalah pendapatan keluarga sangat tergantung pada usaha yang dijalankan } \\
\text { warga dan pekarangan rumah yang sempit menjadi kendala bagi warga untuk menanam } \\
\text { berbagai jenis tanaman yang dapat dijual. Tujuan dari pengabdian ini adalah untuk } \\
\text { meningkatkan pengetahuan warga guna mencari sumber pendapatan baru yang berasal } \\
\text { dari tanaman kelor (bahasa lokal Bengkulu: Remunggai) hingga terampil dalam } \\
\text { mengolah tanaman remunggai menjadi bermanfaat dan bernilai ekonomis bagi }\end{array}$ \\
\hline $\begin{array}{l}\text { Kata Kunci: } \\
\text { Bolu gulung, } \\
\text { Covid-19, } \\
\text { Permen } \\
\text { Produk olahan remunggai, } \\
\text { Remunggai, }\end{array}$ & $\begin{array}{l}\text { pelatihan pembuatan produk olahan dari daun remunggai tersebut. Produk yang } \\
\text { merupakan hasil kegiatan ini adalah bolu gulung dan permen remunggai yang dapat } \\
\text { dikonsumsi sendiri oleh masyarakat atau dijual untuk memperoleh penghasilan } \\
\text { tambahan. Berdasarkan hasil penyuluhan dan pelatihan, pengetahuan warga tentang } \\
\text { tanaman remunggai meningkat dan keterampilan warga dalam membuat produk olahan } \\
\text { juga bertambah sehingga diharapkan dapat menambah pendapatan masyarakat. }\end{array}$ \\
\hline
\end{tabular}

Remunggai,

Keywords:

Candy,

Covid-19,

Moringa oliefera's product

rolls cake
Moringa oliefera

\section{ABSTRACT}

The Covid-19 pandemic era greatly affected the economy of residents in Ratu Samban District, Bengkulu City, Bengkulu Province. The problems encountered are that family's income is very dependent on the business run by residents and the narrow yard of the house becomes an obstacle for residents to plant various types of plants that can be sold. The purpose of this service was to increase the knowledge of citizens to find new sources of income from the Moringa plant (Bengkulu local language: Remunggai) so that they were skilled in processing the remunggai plant to be useful and of economic value for the community. The method used was counseling about the remunggai plant and training in making processed products from the remunggai leaves. The products produced of this activity were roll cakes and remunggai candy which could be consumed by themselves or sold to earn additional income. The knowledge of residents about the remunggai plant has increased and the skills of residents in making processed products have also increased so that it was expected to increase people's income.

ISSN 2685-0354 (Media Online). Diterbitkan oleh Universitas Prof. Dr. Hazairin, SH. Ini merupakan jurnal bebas akses di bawah lisensi Creative Commons Atribution 4.0 International (https://creativecommons.org/licenses/by/4.0

\section{PENDAHULUAN}

Pada tahun 2020 ini, dunia sedang diserang oleh virus corona. Virus Corona adalah suatu kelompok virus yang dapat menyebabkan penyakit pada hewan atau manusia (Yuliana, 2020). Beberapa jenis virus corona dapat 
menyebabkan infeksi saluran nafas pada manusia dengan gejala mulai dari batuk pilek hingga yang lebih serius seperti Middle East Respiratory Syndrome (MERS) dan Severe Acute Respiratory Syndrome (SARS). Virus corona jenis baru yang ditemukan pada tahun 2019 ini menyebabkan penyakit pernafasan yang disebut dengan Covid-19. Covid-19 adalah penyakit menular. Virus dan penyakit ini tidak dikenal sebelum mewabah di Wuhan, Tiongkok, pada bulan Desember 2019. Covid-19 ini sekarang menjadi sebuah pandemi yang terjadi di banyak negara di seluruh dunia. Berdasarkan data dari situs worldometer per 5 Mei 2020, penderita positif virus Corona di dunia sudah mencapai 3,669 juta dengan jumlah yang meninggal 253,183 dan yang sembuh 1,210 juta.

Dampak wabah Covid-19 kepada perekonomian dunia juga sangat dahsyat (Sakti, 2020). Pada triwulan pertama 2020 ini, pertumbuhan ekonomi di sejumlah negara mitra dagang Indonesia tumbuh negatif misalnya Singapura -2.2, Hongkong -8,9, Uni Eropa -2,7 dan China mengalami penurunan sampai -6,8. Beberapa negara masih tumbuh positif namun menurun bila dibanding dengan kuartal sebelumnya. Wabah Covid-19 berpotensi mengubah tatanan ekonomi dunia yang ditandai dengan berubahnya peta perdagangan dunia, selain mengakibatkan mandegnya berbagai bidang usaha (Supriyanto, 2020). Dampak ini juga dialami oleh Indonesia khususnya Kota Bengkulu, terutama bagi masyarakat kelas menengah ke bawah dengan mata pencarian berdagang.

Kota Bengkulu memiliki 9 kecamatan dan 67 kelurahan. Luas wilayahnya mencapai $151,70 \mathrm{~km}^{2}$ dan penduduk 364.604 jiwa (2017) dengan sebaran 2.403 jiwa km-2. Kecamatan yang menjadi sasaran program adalah Kecamatan Ratu Samban yang memiliki 9 kelurahan yang mana 6 kelurahan di antara kelurahan tersebut dijadikan desa lokasi kegiatan pengabdian kepada masyarakat ini. Masyarakat Kecamatan Ratu Samban umumnya memiliki mata pencaharian sebagai pegawai, buruh lepas dan pedagang dan merasakan dampak negatif dari pandemi Covid-19 terhadap perekonomian. Solusi dari permasalahan ekonomi di tengah pandemic Covid-19 yang dapat diberikan oleh tim pengabdi adalah pemanfaatan tanaman kelor.

Kelor atau nama local Bengkulu disebut remunggai (Moringa oleifera) merupakan tanaman dari suku Moringaceae. Daunnya berbentuk oval dengan ukuran kecil yang tersusun rapi dalam satu tangkai. Pohon remunggai dapat tumbuh tinggi hingga mencapai 7-11 meter, berhiaskan bunga cantik berwarna putih kekuning-kuningan yang mengeluarkan aroma semerbak. Tanaman remunggai berasal dari India sub-Himalaya dan telah lama menjadi salah satu unsur penting dalam pengobatan Ayurveda sebagai obat untuk lebih dari 300 penyakit. Tanaman daun remunggai merupakan salah satu dari 13 spesies dalam genus yang sama dan telah menyebar di daerah tropis dan subtropis pada ketinggian hingga $2.000 \mathrm{~m}$ (Leone et al.,2019).

Berdasarkan hasil penelitian yang dilaporkan oleh Tapriadi dan Jupriyono (2018), daun remunggai dapat dibuat menjadi beberapa produk makanan olahan yang dapat meningkatkan penghasilan warga. Tanaman remunggai terutama daunnya sering dijadikan sebagai bahan dasar obat dan sayur. Beberapa bentuk olahan atau bentuk konsumsi remunggai adalah sisa air rebusan dari daun remunggai, jamu, teh, loloh sayur. Air rebusan daun remunggai tetap mengandung senyawa-senyawa yang aktif sebagai antioksidan dan beberapa vitamin larut dalam air.

Di dalam daun remunggai terkandung potasium yang jumlahnya 3 kali lebih besar dari pisang, vitamin A yang 4 kali lebih melimpah dibandingkan wortel, vitamin $C$ yang 7 kali lebih besar dari jeruk dan kadar kalsium yang 4 kali lebih banyak dari susu. Selain itu nutrisi yang dikandung oleh remunggai adalah protein, vitamin A (B-karoten), dan zat besinya (Singh et al., 2013; Madukwe, et al., 2013). Daun remunggai menurut Kusmardika (2020) memiliki kandungan antioksidan dan senyawa bioaktif yang tinggi sehingga berpotensi untuk mencegah terjadinya stress oksidatif dan kanker. Berdasarkan penelitian Paramitha (2020) remunggai kaya akan antioksi dan menurut Kasolo et al. (2010) mengandung tannin, steroid, triterpenoid, flavonoid, saponin, antarquinon, dan alkaloid yang semuanya merupakan antioksidan. Fungsi antioksidan adalah untuk memperbaiki sel dari kerusakan. Oleh karena itu, remunggai kemungkinan dapat membantu proses penyembuhan sel yang ada di paru-paru akibat serangan virus yang sekarang mewabah. Remunggai dapat meningkatkan imunitas tubuh karena mineral dan vitamin dalam remunggai juga banyak.

Kegiatan ini bertujuan untuk memberikan alternatif jalan keluar bagi permasalahan kesehatan dan perekonomian yang melanda masyarakat di masa pandemi yaitu pemanfaatan tanaman remunggai. Permasalahannya adalah bagaimana meningkatkan pengetahuan warga tentang tanaman remunggai dan manfaatnya, serta bagaimana meningkatkan keterampilan warga dalam membuat produk olahan berbahan baku remunggai untuk meningkatkan kesejahteraan dan perekonomian warga di kecamatan Ratu Samban

\section{METODE}

Kegiatan pengabdian pada masyarakat dilaksanakan pada tanggal 1 Juli hingga 10 Agustus 2020 di 6 kelurahan selingkung Kecamatan Ratu Samban, Kota Bengkulu, Provinsi Bengkulu. Kegiatan ini melibatkan mahasiswa dalam 
hal pengumpulan data. Peserta kegiatan berjumlah 60 orang yang dipilih berdasarkan tingkat perekonomian menengah ke bawah. Tim pengabdi terlebih dahulu berkoordinasi dengan pemerintah setempat untuk sosialisasi program dan untuk memilih warga masyarakat yang akan mengikuti program pengabdian pada masyarakat.

Program ini dilaksanakan melalui 5 tahap. (1) Tahap pertama adalah identifikasi masalah di lapangan dan pendataan warga sasaran. (2) Tahap kedua adalah pembagian bibit serta cara pembudidayaan tanaman remunggai. Bibit yang diberikan berupa tanaman remunggai yang telah ditanam di dalam planter bag. (3) Tahap ketiga adalah sosialisasi tentang tanaman remunggai dan manfaatnya. Sosialisasi dilakukan dengan pemberian materi dan bimbingan teknis perawatan tanaman remunggai. (4) Tahap keempat adalah praktek pengolahan daun remunggai menjadi berbagai produk olahan seperti bolu gulung, keripik bawang, kue sobek, martabak mini, rempeyek dan permen. Alat yang digunakan adalah mixer, wajan, kompor, blender, pisau dan pemanggang kue. (5) Tahap kelima adalah pelatihan pengemasan dan pelabelan.

Monitoring dan evaluasi dilakukan terhadap pertumbuhan tanaman untuk melihat antusiasme warga dalam merawat bibit tanaman remunggai dan pengolahan menjadi produk makanan. Kegiatan pengambilan data dilakukan dengan survei dan observasi lapangan, wawancara dan angket terhadap warga sasaran. Parameter yang diamati di antaranya peningkatan pengetahuan dan keterampilan dalam hal pemanfaatan pekarangan sempit, pemeliharaan dan budidaya tanaman remunggai, serta pengolahan tanaman remunggai menjadi produk makanan. Pengumpulan data dilakukan sebelum kegiatan dan sesudah kegiatan.

\section{HASIL DAN PEMBAHASAN}

Hasil survei dan observasi menggambarkan adanya permasalahan, potensi dan alternatif pemecahan masalah yang dapat dikerjakan bersama dengan warga. Alternatif pemecahan masalah yang ditawarkan mengutamakan kebutuhan dan keinginan warga sebagai mitra pengabdian. Tim pengabdi menjadi fasilitator dengan mengintegrasikan ilmu pengetahuan dan teknologi dan penerapan hasil penelitian. Beberapa masalah dan potensi yang ada di lokasi pengabdian adalah (1) tingkat ekonomi warga menengah ke bawah dengan pekerjaan warga produktif tidak menentu dan penghasilan menurun di masa pandemi Covid-19. (2) Warga tidak memiliki keahlian lain di luar pekerjaannya baik sebagai buruh harian, pedagang, ibu rumah tangga dan pekerjaan tidak tetap lainnya. (3) Pekarangan sedikit dan bukan berupa tanah yang dapat ditanam. (4) Keterampilan budidaya tanaman rendah. (5) Pengetahuan terhadap pengolahan tanaman remunggai kurang.

Hasil diskusi dengan mengintegrasikan ilmu dan pengetahuan terkait dengan permasalahan dan potensi yang ada maka beberapa solusi yang ditawarkan dapat diterima dan dilaksanakan dalam kegiatan pengabdian. Pada prinsipnya kegiatan pengabdian menawarkan solusi untuk (1) memberikan pengetahuan dan keterampilaan berwirausaha untuk membantu perekonomian warga. (2) Memberikan keterampilan kerja berwirausaha untuk membantu perekonomian keluarga. (3) Sosialisasi dan penyerahan bibit tanaman remunggai menggunakan planter bag. (4) Pelatihan budidaya tanaman remunggai. (5) Pelatihan keterampilan membuat produk olahan berbahan dasar remunggai, pengemasan pelabelan dan teknik pemasaran.

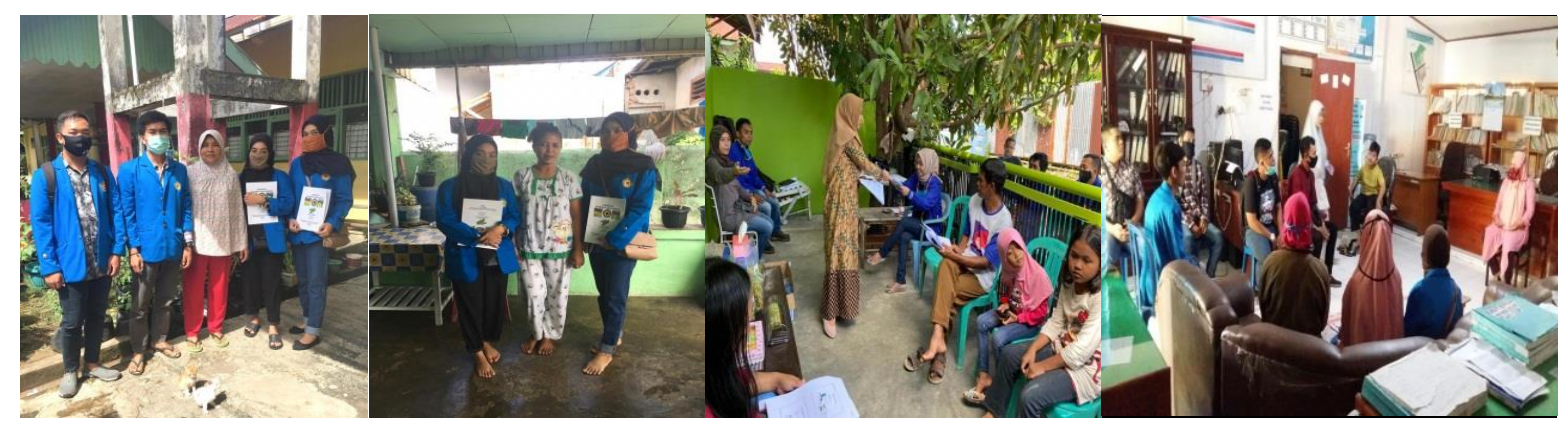

Gambar 1 Identifikasi masalah dan pendataan warga sasaran

Program pengabdian kepada masyarakat ini secara berurutan dimulai dari identifikasi dan pendataan warga sasaran, penyerahan bibit dan sosialisasi cara budidaya tanaman remunggai, sosialisasi tanaman remunggai dan pemanfaatannya, dan pengolahan tanaman menjadi produk olahan. Pada tahap awal, identifikasi masalah dilaksanakan di lokasi sekaligus untuk pendataan warga sasaran yang akan mendapatkan bibit remunggai. Warga yang dijadikan sasaran adalah warga yang berpenghasilan menengah ke bawah (Gambar 1). Survei dan observasi dilaksanakan pada 6 kelurahan. Tim pengabdi dibantu oleh mahasiswa melakukan kunjungan lapangan guna melihat secara langsung 
kondisi permukiman warga dan mendata warga yang bersedia untuk menerima bibit remunggai. Setiap kelurahan dipilih 100 warga sasaran yang akan dijadikan sampel guna mengetahui tingkat pengetahuan warga tentang tanaman remunggai.

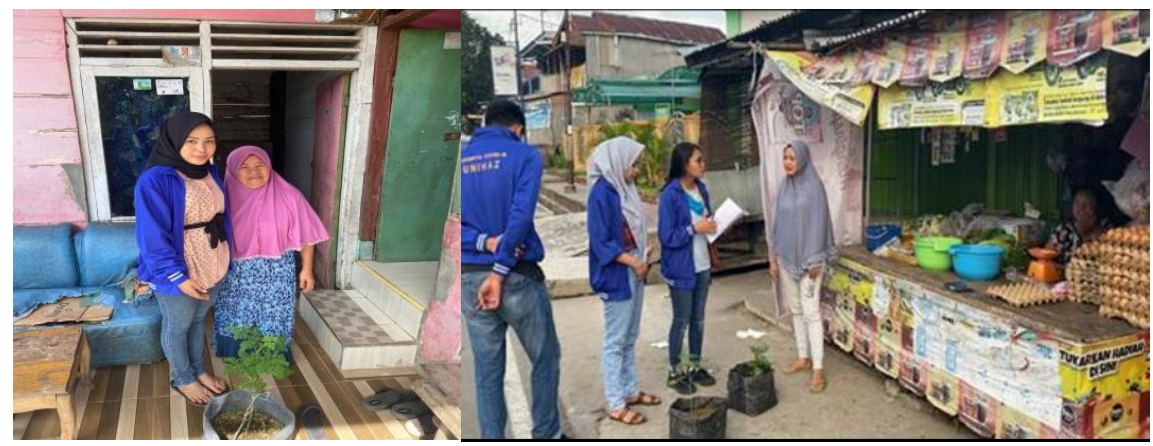

Gambar 2 Pembagian bibit dan sosialisasi tanaman remunggai, dan cara budidaya

Pembagian bibit kepada warga sasaran dilakukan sesuai dengan data yang telah dikumpulkan sebelumnya. Masyarakat disuluh tentang tanaman remunggai, manfaat dan cara budidaya tanaman tersebut bersamaan dengan penyerahan bibit kepada warga. Materi sosialisasi terdiri atas 1) Pemanfaatan pekarangan dengan tanaman menggunakan planter bag, dan 2) Cara budidaya tanaman remunggai (Gambar 2). Sosialisasi ini bertujuan untuk memberikan informasi tentang bagaimana memanfaatkan pekarangan yang sempit dan memelihara tanaman yang bernilai gizi dan bernilai ekonomis. Selain itu kegiatan ini memberikan gambaran kepada warga supaya dapat mengoptimalkan pengolahan tanaman remunggai untuk meningkatkan kesejahteraan warga serta dapat menambah penghasilan.

Kegiatan dilanjutkan dengan sosialisasi tentang tanaman remunggai dan manfaatnya. Kegiatan ini diperlukan karena tidak semua warga mengetahui tanaman remunggai dan kandungan gizi yang ada di dalam tanaman tersebut serta manfaat dari tanaman ini (Gambar 3). Menurut Simbolon et al. (2007), kandungan kimia yang dimiliki daun remunggai yakin asam amino yang berbentuk asam aspartat, asam glutamate, alanin, valin, leusin, isoleusin, histidin, lisin, arginin, venilalanin, triftopan, sistein, dan methionin. Daun remunggai juga mengandung makro elemen seperti potasium, kalsium, magnesium, sodium, dan fosfor serta mikro elemen seperti mangan, zinc dan besi. Daun remunggai merupakan sumber provitamin a, vitamin b, vitamin c, mneral terutama zat besi.

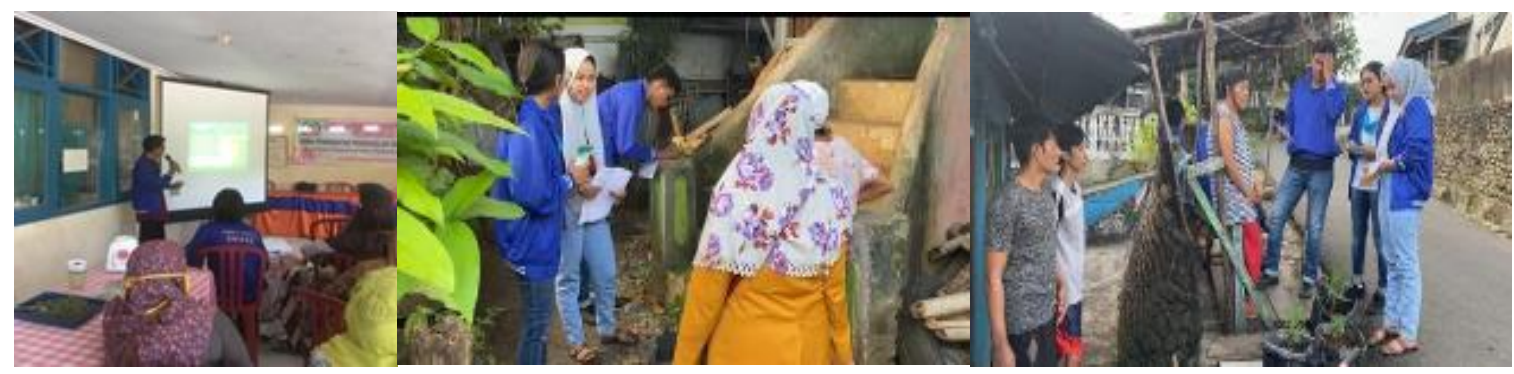

Gambar 3 Sosialisasai tanaman remunggai dan manfaatnya

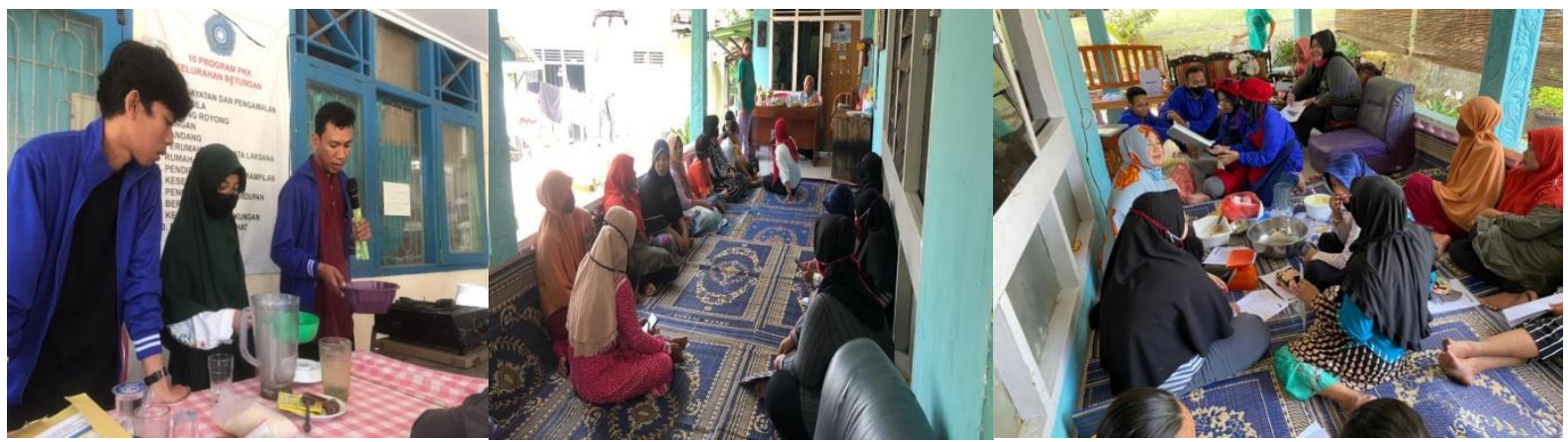

Gambar 4 Pelatihan pembuatan produk olahan dari tanaman remunggai 
Selain dimasak menjadi olahan sayur, daun remunggai juga dapat dibuat menjadi bolu gulung, keripik bawang, kue sobek, martabak mini, rempeyek dan permen. Proses pembuatan produk olahan ini dilakukan bekerjasama dengan Usaha Mikro Kecil dan Menengah (UMKM) yang berada di salah satu kelurahan. Pembuatan produk ini mudah dan peralatan yang digunakan relatif sederhana dan rendah modal. Tujuan pelatihan pembuatan produk ini adalah untuk meningkatkan keterampilan warga sasaran dalam mensejahterakan keluarga dalam hal kesehatan dan ekonomi, sehingga dapat menjadi salah satu alternatif dalam menghadapi masa pandemi Covid-19. Produk olahan rumah tangga ini dapat dikembangkan dan dipasarkan melalui UMKM maupun dipasarkan secara mandiri oleh warga (Gambar 4).

Produk olahan yang menjadi perioritas pengabdian kepada masyarakat ini yaitu bolu gulung remunggai dan permen remunggai. Warga sasaran diberikan pelatihan khusus cara membuat produk olahan dan juga diberikan informasi mengenai kandungan yang terdapat pada produk olahan. Bolu gulung remunggai dibuat menggunakan bahan telur, gula, baking powder, emulsifier, dan daun remunggai yang telah diblender dan disaring untuk diambil air sari daunnya. Proses pembuatan bolu dimulai dari pengocokan telur sehingga terbentuk foaming, penggabungan air pati remunggai, dan pemanggangan di dalam oven. Pengikatan air oleh pati terjadi selama pemanasan (Andriani \& Toha, 2012). Selain itu, kadar amilosa dan amilopektin juga mempengaruhi daya kembang dari cake. Cake dengan bahan beramilosa tinggi cenderung memiliki rongga yang makin kecil atau makin rapat karena amilosa mampu membentuk kristal yang lebih besar (Anggraini et al., 2017). Cabang amilopektin berkontribusi dalam peningkatan nilai pengembangan karena amilopektin mudah menangkap air (Imam et al., 2014). Bolu yang telah matang diolesi dengan selai remunggai. Selai remunggai dibuat dari air sari remunggai yang dimasak dengan gula sampai membentuk selai. Bolu yang telah dioles selai digulung perlahan dan didinginkan pada suhu ruang untuk siap dikonsumsi.

Inovasi lainnya adalah pemanfaatan bubuk daun remunggai dalam bentuk permen jeli. Permen jeli merupakan salah satu jenis kudapan yang disukai oleh hampir semua golongan usia, terutama anak-anak. Permen jeli disukai karena rasanya yang manis dan juga teksturnya yang unik. Selain itu, permen jeli dapat diolah dengan berbagai macam variasi baik dari bahan baku, rasa, warna, dan juga bentuk yang menarik. Jenis kudapan confectionery atau gula-gula semacam permen dapat menggantikan energi yang hilang dengan cepat (Kouevi, 2013). Bahan yang digunakan untuk pembuatan permen adalah daun remunggai yang dikeringkan lalu dihancurkan hingga menjadi bubuk, gelatin, gula, glukosa sirup, air, asam sitrat, essence, pewarna makanan, dan Na. benzoat. Permen jeli dibuat dari bubuk daun remunggai dengan proporsi bubuk remunggai: air adalah 1:5. Campuran air, gula, dan glukosa sirup dipanaskan hingga mencapai suhu $80-90^{\circ} \mathrm{C}$. Bubuk daun remunggai dimasukkan dan diaduk secara merata hingga mencapai suhu 100$110^{\circ} \mathrm{C}$. Setelah itu, gelatin yang telah dilarutkan dengan air $\left(70^{\circ} \mathrm{C}\right)$ ditambahkan essens dan pewarna secukupnya agar warna permen yang dihasilkan lebih menarik. Permen jeli yang telah dituang ke dalam cetakan disimpan pada suhu ruangan $\left(27^{\circ} \mathrm{C}\right)$ dengan ditutup menggunakan aluminium foil selama 24 jam. Terakhir, permen tersebut dikeluarkan dari cetakan dan dilapisi dengan tepung tapioca dan tepung gula yang telah disangrai terlebih dahulu dengan perbandingan $1: 1$.

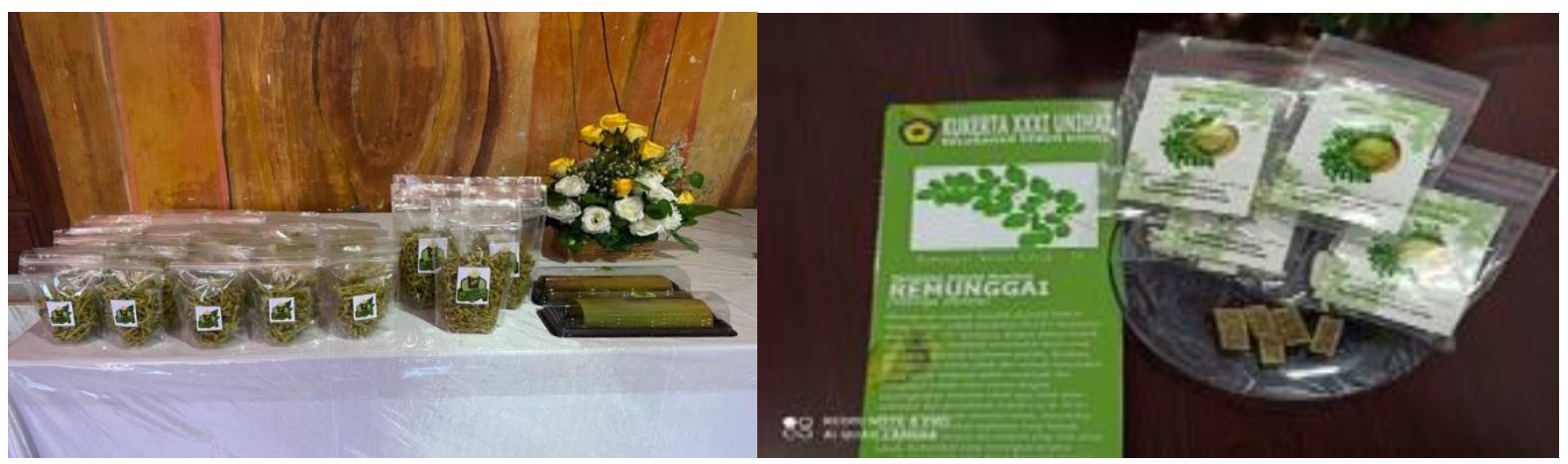

Gambar 5 Pengemasan dan pelabelan produk olahan

Pengemasan diperlukan untuk menarik minat konsumen dan untuk melindungi produk (Amarul et al., 2018). Kemasan yang baik dapat membangun ekuitas merek dan mendorong penjualan (Kotler \& Keller, 2012). Pada tahap ini, warga dikenalkan beberapa jenis kemasan yang memungkinkan digunakan untuk produk yang dibuat (Gambar 5). Untuk mencapai tujuan ekonomis dari kegiatan pengabdian ini, mitra pengabdian dikenalkan konsep pemasaran. Materi ini dipaparkan secara sederhana agar lebih mudah dimengerti oleh warga mitra. Alasan pengenalan konsep pemasaran adalah agar warga mengetahui dan menentukan strategi yang pemasaran untuk mencapai target penjualan yang diinginkan. 
Pemantauan dan evaluasi dilakuan untuk memantau pertumbuhan bibit dan memberikan masukan kepada warga yang menerima bibit apabila mengalami permasalahn dalam hal pemeliharaan tanaman (Gambar 6). Selain itu monitoring juga dilakukan terhadap peningkatan keterampilan warga dalam membuat produk yang telah diperagakan dengan mengajarkan warga melihat peluang untuk memasarkan produk melalui media online (Gambar 7). Hasil pemantauan dan evaluasi menunjukkan terjadinya peningkatan keterampilan warga dalam memelihara tanaman remunggai dan pengolahan tanaman remunggai menjadi produk olahan yang bergizi serta bernilai ekonomis. Kegiatan ini juga dipublikasikan melalui media massa lokal dan nasional (Gambar 8).

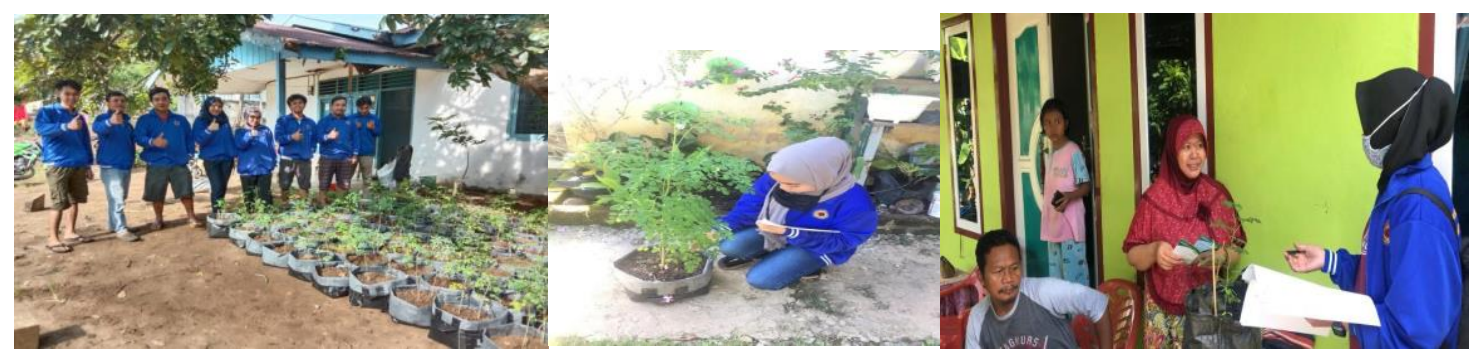

Gambar 6 Monitoring Pertumbuhan bibit

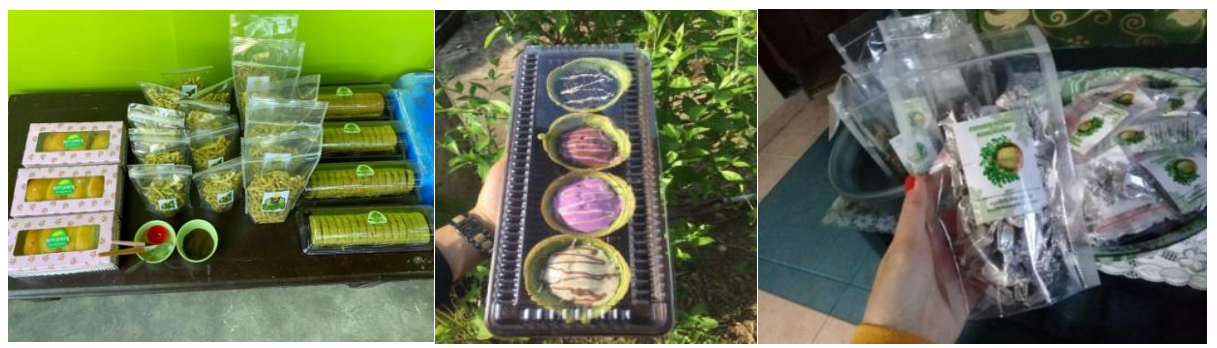

Gambar 7 Monitoring Peningkatan Keterampilan warga dalam hal pengemasan produk dan pemasaran
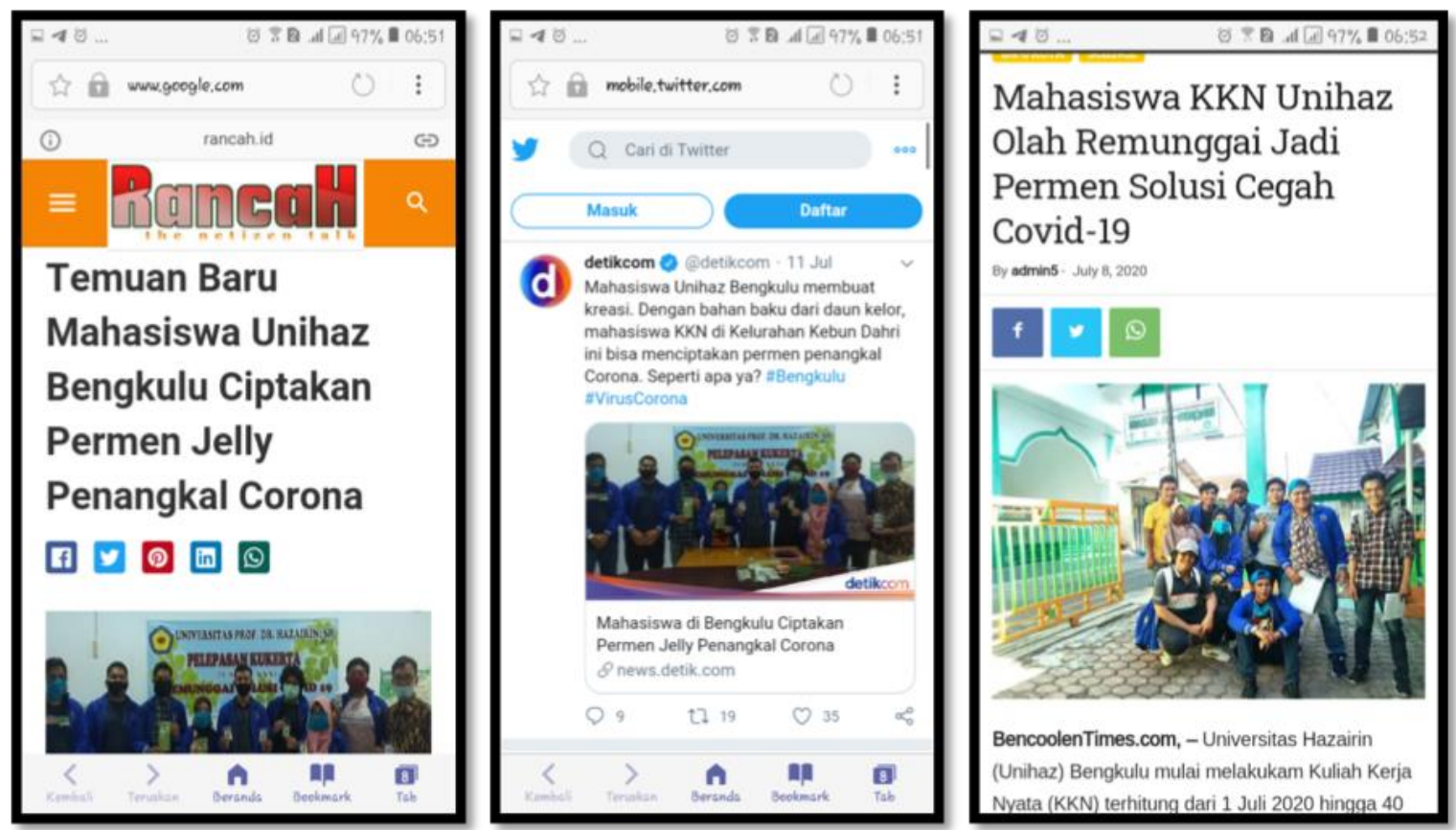

Gambar 8 Pemberitaan mengenai kegiatan pengabdian dan olahan remunggai

Pasca kegiatan, warga memiliki produk layak jual berupa bolu gulung, keripik, roti sobek, martabak mini, permen dan rempeyek remunggai yang telah diberi kemasan dan label. Selain kemampuan menghasilkan produk, warga juga memiliki pengetahuan tentang pemasaran produk untuk selanjutnya dapat melakukan penjualan produk secara offline maupun melalui media sosial. 


\section{KESIMPULAN}

Program pengabdian kepada masyarakat ini telah menjadikan warga di Kecamatan Ratu Samban memiliki pengetahuan dan keterampilan pengelolaan pekarangan dan pembuatan produk olahan berbahan baku tanaman remunggai. Kegiatan ini dapat menjadi ladang bisnis yang dapat membantu keuangan keluarga serta meningkatkan kesehatan serta kesejahteraan warga. Keterampilan ini diharapkan dapat menjadi modal warga untuk lebih kreatif dalam menghadapi masa pandemi covid. Saran yang dapat disampaikan adalah perlu adanya keberlanjutan program dan kerjasama dengan berbagai instansi terkait guna membantu warga memasarkan produknya.

\section{UCAPAN TERIMA KASIH}

Terimakasih kepada Lembaga Penelitian dan Pengabdian kepada Masyarakat Universitas Prof. Dr. Hazairin, SH Bengkulu yang telah mendanai kegiatan ini.

\section{DAFTAR PUSTAKA}

Amarul, A., Sukirno, S., \& Andari, A. (2018). Pemahaman pentingnya kemasan terhadap pelaku usaha berdasarkan rentang variasi lama usaha. Jurnal Mitra Manajemen, 2(6), 610-618

Andriani, D., \& Toha, M. (2012). Metode Penelitian. Universitas Terbuka.

Anggraini, T., Dewi, Y. K., \& Sayuti, K. (2017). Karakteristik sponge cake berbahan dasar tepung beras merah, hitam, dan putih dari beberapa daerah di Sumatera Barat. Jurnal Litbang Industri, 7(2), 123-136.

Singh, R. S. G., Negi, P. S., \& Radha, C. (2013). Phenolic composition, antioxidant and antimicrobial activities of free and bound phenolic extracts of Moringa oleifera seed flour. Journal of Functional Foods, 5(4), 18831891.

Imam, R. H., Primaniarta, M, \& Palupi, N. S. (2014). Konsistensi mutu pilus tepung tapioka: identifikasi parameter utama penentu kerenyahan. Jurnal Mutu Pangan, 1(2), 91-99.

Kasolo, J. N., Bimenya, G. S., Ojok, L., Ochieng, J., \& Ogwal-Okeng, J. W. (2010). Phytochemicals and uses of Moringa oleifera leaves in Urgandan rural communities. Journal of Mediciinal Plants Research, 4(9), 753757.

Kotler, P., \& Keller, K. L. (2012). Manajemen Pemasaran. Erlangga

Kouevi, K. K. (2013). A study on moringa oleifera leaves as a supplement to West African weaning foods. University of Aplied Science.

Kusmardika, D. A. (2020). Potensi aktivitas antioksidan daun kelor (Moringa oleifera) dalam mencegahan kanker. Journal of Health Science and Physiotherapy, 2(1), 46-50.

Leone, A., Spada, A., Battezzati, A., Schiradi, A., Aristil, J., \& Bertoli, S. (2015). Cultivation, genetic, ethnophatmacology, phtochemistry and pharmacology of Moringa oleifera leaves: An overview. International Journal of Molecular Sciences, 16(6), 12791-12835.

Madukwe, E., Ugwuoke, A. \& Ezeugwu, J. (2013). Effectiveness of dry Moringa oleifera leave powder in treatment of anemia. AcademicJournals, 5(5), 226-228.

Sakti, N. W. (2020). Perekonomian Indonesia pasca-pandemi Covid-19. Harian Kompas. https://money.kompas.com/read/2020/05/10/091500226/perekonomian-indonesia-pasca-pandemi-Covid19? page $=$ all.

Simbolon, J. M., Katharina, N., \& Sitorus, M. (2007). Cegah malnutrisi dengan kelor. Kanisius.

Supriyanto, B. (2020). Dampak pandemi Covid-19, Ekonomi Indonesia diperkirakan pulih 2022. Harian Bisnis. https://ekonomi.bisnis.com/read/20200427/9/1233454/dampak-pandemi-Covid-19-ekonomi-indonesiadiperkirakan-pulih-2022

Tapriadi, \& Jupriyono. (2018). Pemanfaatan daun kelor sebagai jajanan sehat dalam rangka pemberdayaan masyarakat Kelurahan Bareng di Kota Malang. Jurnal Idaman, 2(1), 27-29.

Yuliana, Y. (2020). Corona virus diseases (Covid-19): Sebuah tinjauan literatur. Wellness And Healthy Magazine, 2(1), 187-192. 